\title{
Seed Treatment of Capsicum annuum with Two Different Fungicides to Evaluate the Seed Germination Rate
}

\author{
Arzlan Abbas $^{1} \quad$ Saddam Hussain $^{2} \quad$ Asim Iqbal $^{1} \quad$ Muhammad Ali $^{2} \quad$ Amir Shehzad $^{2}$ \\ Muhammad Usman ${ }^{2} \quad$ Pervaiz Iqbal $^{2} \quad$ Chenri Zhao $^{1^{*}}$ \\ 1.College of Plant Protection, Jilin Agricultural University, Changchun 130118, PR China \\ 2.Department of Entomology, Faculty of Agriculture, University of Agriculture Faisalabad, 38000, Pakistan.
}

\begin{abstract}
Chili (Capsicum annuum L.) is the fruit of plants, the Chili is susceptible for several diseases and seed borne fungi Phytophthora capsici which produces collar rot and root of chili. Seed borne pathogens are associated with untreated seeds of chili which are also significantly reduced the germination of seed. This experiment was conducted to find out the seed borne fungi and enhanced the germination of chili (Capsicum annuum) with two fungicides known as Mancozeb 80\% WP and Carbendazim 50\% WP. Effectiveness of these two fungicides were measured when the seeds planted on blotter paper in petri plates at $27^{\circ} \mathrm{C}$ under lab conditions. These two fungicides significantly reduce the effect of seed borne fungi associated with chili seeds. Mancozeb $80 \%$ WP was found most effective to reduce the effect of seed borne fungi and increase the seed germination. Considering the results of the experiment, Mancozeb $80 \%$ WP was noted to be a best fungicide against the seed borne fungi.
\end{abstract}

Keywords: Capsicum annuum, Mancozeb, Carbendazim, seed borne fungi, blotter paper.

DOI: $10.7176 / \mathrm{JBAH} / 10-4-04$

Publication date: February $29^{\text {th }} 2020$

\section{Introduction}

Chili (Capsicum annuum L.) is the fruit of plants from the genus 'Capsicum', members of the nightshade family, 'Solanaceae' (Asaduzzaman et al. 2010), widely growing in all season and all areas of Pakistan. Chili (Capsicum annum L.) is an important vegetable crop planted over an estimated area of 47.3 thousand hectares with an annual production of 69.5 thousand tones, with an average yield of $1902 \mathrm{~kg} / \mathrm{ha}$ in Pakistan (Anon 2006). Chilies are widely grown as cash crop, spice and vegetable crop in the tropical and subtropical regions. (Hemannavar 2008 \& Than et al. 2008). Capsicum annum (frutescens) exists as an annual herbaceous vegetable or perennial shrub of the Solanacae (Amusa et al. 2004). Pepper is suitable for diets of the overweight and is also useful in the control of cancer of the stomach and colon (Pamplona-Roger 2007). Globally chilies production of 7.18 million tons over an area of 1.7 million ha (Anon 2014). Capsicum spp. are rich in Vitamin A, Vitamin C and Vitamin D (T.R. Chauhan et al. 2018) and are also very good source of potassium, folic acid, vitamin $\mathrm{E}$ and low in sodium and cholesterol free (Than et al. 2008).

Seed is important for crop production and increase the yield of crop about $90 \%$ world food crop is Capsicum annuum L (Maude 1996). Seeds of chili or other crop is the passive input of carrier of seed borne pathogens like as bacteria, fungi, nematode and viruses can be carried with the seed (E. Chigoziri \& E.J. Ebenezer 2013). Chili is susceptible for several diseases and seed borne fungi Phytophthora capsici produces collar rot and root of chili (Ahmed et al. 1989; Saleem et al. 1996; 1998 \& Hussain et al. 1990), Collectotrichum spp caused fruit rot and die-back or anthracnose of Capsicum annuum L (Khaleeque \& Khan 1991; Sultana et al. 1992 \& Amusa 2004) Fusarium spp produces wilt, root rot and powdery mildew is caused by the Leveillula taurica (Hafeez 1986; Mushtaq \& Hashmi 1997). Seed borne and air borne diseases of chili affects the seed germination and vigour to a greater extent (Ahmed 1982; Perane \& Joi 1988; Mesta 1996 \& Asalmol et al. 2001).

Seed treatment of chilies is a progression of treating seeds by chemical, physical, biological and other agent(s) to terminate harmful seed-borne fungi and to protect the seeds against infection. It is done to prevent germination failure and seedling infection, to destroy external and internal seed borne fungi and to develop a protective zone around the seed in the soil which protects the germinating seed, health of the seed and seedling from the attack of certain soil borne fungi. To increase the production of chili both qualitatively and quantitatively; farmer requires healthy and quality seeds with high percentage of germination and purity.

\section{Materials and Methods}

This experiment was performed during 01-05-2019 to 21-05-2019 in Microbial lab of Plant Pathology Department University of Agriculture, Faisalabad, Pakistan. Seeds of Desi chili variety were collected from the certified seed merchant. To find out the efficacy of different fungicides to control the seed borne fungi (pathogens) in chilies seed, fungicides namely Mancozeb 80\% WP and Carbendazim 50\% WP. The Seeds were sown on wet blotter paper; 15 seed in an outer most line, 9 seed in middle line and 1 seed at center of Petri plate (Islam. S. S., et al. 2007). Incubate the plates inside the incubator at $27-30^{\circ \mathrm{C}}$ and keep the blotter paper moist. 
Make the dilution of two fungicides Mancozeb $80 \% \mathrm{WP}$ at concentration (conc.) (1.562gm, 0.781gm, 0.39gm and $0.195 \mathrm{gm}$ ) and Carbendazim 50\% WP at conc. (1 gm, 0.5gm, 0.25gm and $0.125 \mathrm{gm})$. Seeds of chilies were treated with prepared dilution of fungicides separately by dipping method for 15 minutes. The treated seeds were soaked with blotter paper and placed on moist blotter paper to determine the seed germination.

2.1.1. Seed health test by blotter paper method:

Detection of the seed borne pathogens by blotter paper method by International rule of seed testing method (ISTA 1996). Blotter paper were soaked into sterilized water and placed at the bottom of $9 \mathrm{~cm}$ diameter of petri plates, 25 seeds were placed in each petri plates. In each treatment, 15 replications (petri plates) were used and 375 seeds were placed. These seeds in petri plates were incubated at $27^{\circ \mathrm{C}}$ under microbial lab condition. The occurrence of Aspergilla nigrais, Aspergilla's fulvous and Alternaria spp. and germination were recorded by following blotter method designated earlier (Anon 1976).

2.1.2. Detection of pathogens:

Fungal species Aspergilla's flavous and Aspergilla's nigras were identified by preparing slides and viewing spores under compound microscope (X 40-X 100 magnifications) for the presence of fungi (E. Chigoziri \& E.J. Ebenezer et al. 2013), identification of these fungal pathogens on the base of spores, morphology and colony of characters (Barnett \& Hunter 1972, \& Ellis 1971).

2.1.3. Statistical analysis:

The experiment was conducted by following the CRD (complete randomized design). The data collected from experiment was analyzed by the appropriate statistical software.

\section{Results and Discussion}

Seed borne pathogens are associated with untreated seeds of chili which are significantly reduced the germination of seed. All type of treated seed completely eliminates the seed borne fungi and improves the germination of seed and ultimately increases the yield of crop. Table.1. Highest seed germination was recorded in Mancozeb 80\% WP, 82\% germination and lowest germination was recorded in control condition 53\%. The seed germination was obtained about $29 \%$. Significant differences were observed between treatments and control as well as among the treatment. Highest healthy seed germination was recorded in Mancozeb $80 \%$ WP at conc. (1.562 gm $100 \%$ and $0.39 \mathrm{gm} 97.32 \%$ healthy plants and $1.562 \mathrm{gm} \%$ and $0.39 \mathrm{gm} 2.68 \%$ infected plants) infected plants in control condition was $46.68 \%$. Table.2. Similarly healthy and infected percentage of chili seeds treated with Carbendazim 50\% WP $1 \mathrm{gm}$ and $0.25 \mathrm{gm}$ gives similar result upto $92 \%$ and $93.36 \%$ healthy plants and $8 \%$ \& $6.68 \%$ infected plants. In control conditions $40 \%$ infected plants were recorded.

Fig.1. chili seeds treated with Mancozeb $80 \%$ wp with different conc. $(1.562 \mathrm{mg}, 0.781 \mathrm{mg}, 0.39 \mathrm{mg}$, $0.195 \mathrm{mg}$ and control) gives Germination percentages of $76 \%, 82.67 \%, 82.67 \%, 80 \%$ and $53.3 \%$. Data analyzed from Fig. 1. revealed that chilli seeds treated with the application of Mancozeb $80 \% \mathrm{wp}$ (Conc. $/ \mathrm{mg}$ ) $0.782 \mathrm{gm}$ and $0.39 \mathrm{mg}$ gives higher Germination percentage. Fig.2. the chilli seeds treated with Carbendazim 50\% wp (Conc. $/ \mathrm{mg})(0.125 \mathrm{mg}, 0.25 \mathrm{mg}, 0.5 \mathrm{mg}, 1 \mathrm{mg}$ and control) gives germination percentages of the chilli seeds upto $80 \%, 80 \%, 53.3 \%, 74.7 \%$ and $70.7 \%$. Data analyzed specified that at conc. of $(0.125 \mathrm{mg}$ and $0.25 \mathrm{mg})$ higher germination percentages $80 \%$ were recorded. Fig.3. it has been shown that healthy and infected percentage of chili seeds treated with Carbendazim 50\% WP $1 \mathrm{gm}$ and $0.25 \mathrm{gm}$ gives higher germination of seed upto $92 \%$ and $93.36 \%$ healthy plants and $8 \% \& 6.68 \%$ infected plants. In control condition, the $40 \%$ infected plants were recorded. Fig.4. Data presented revealed that highest seed germination was recorded in Mancozeb $80 \%$ WP, $82 \%$ germination and lowest germination was recorded in control condition 53\%. The seed germination was obtained about 29\%. Highest healthy seed germination was recorded in Mancozeb 80\% WP at conc. (1.562gm 100\% and $0.39 \mathrm{gm} 97.32 \%$ healthy plants and $1.562 \mathrm{gm} 0 \%$ and $0.39 \mathrm{gm} 2.68 \%$ infected plants) infected plants in control condition was 46.68\%. Fig.5. Infection levels of two fungal species Aspergilla's flavous and Aspergilla's nigras were recorded as the percentage of the infected seeds in a sample as shown in fig A and B after germination.

(Suthin Raj \& Christopher 2009), revealed that seed treatment with Trichoderma harzianum $(10 \mathrm{~g} / \mathrm{kg})$ and Pseudomonas fluorescens $(5 \mathrm{~g} / \mathrm{kg}$ ) reduces $24.10 \%$ and $25 \%$ occurrence of Colletotrichum capsici and enhanced seedling vigour of chilli by $12.10 \%$ and $13.70 \%$ respectively. $P$. fluorescens showed higher antagonistic activity against $C$. capsici under in-vitro conditions and also less seedling rot was gained in $P$. fluorescens treated seeds compared to T. harzianum (Hegde et al. 2001, Srinivas et al. 2006 \& Azad et al. 2013). (Choudhary et al. 2013), reported that seed treatment with thiram, carbendazim and T. viride control seedling rot caused by $C$. capsici. (Adiver et al. 1987), observed that in chilli the most commonly occurring seed borne fungi are Colletotrichum, Cladosporium, Alternaria, Curvularia, and Drechslera species which affect root elongation utterly than shoot elongation. (Koteshwar-Rao et al. 1962), reported that seed treatment of chilli with thiram enhanced in emergence. (Grover \& Bansal 1970), reported that the seeds treated with thiram, captan and brassicol were found to be more better in controlling Colletotrichum capsici. (Narein \& Panigrahi 1971), tested eight fungicides and observed that among of them, zirum was the most effective fungicide for the conidial emergence of Colletotrichum capsici in chilli. (Dhawale 1975), revealed that the seed dressing fungicides viz., thiram, thiovit 
and captafol@2.0 g per kg were effective in eradicating chilli seed mycoflora. (Jharia et al. 1977), tested nine fungicides, found that thiram + captan $(1: 1)$ per cent by weight was highly effective in testing the pre and post emergence losses and mortality at adult stage in chillies and also resulted in higher yields. (Siddique et al. 1977), revealed that with thiram at 0.20 per cent concentration, the best control of Colletotrichum dematium on capcicum was achieved. (Srivastava \& Gupta 1981), found that seed treatment with dithane M 45 at 0.30 per cent, cerason dry at 0.40 per cent or Aureofungin at 0.01 per cent gave good control of seed borne fungi and enhanced the seed germination in chilli. (Kumar \& Mahmood 1986), to control the infestation of Colletotrichum capsici in chilli, they tested seed with 12 different fungicides. They found that highest values noted in case of Aureofungin followed by thiram, bavistin, defolaton and captan. (Dhyani et al. 1991), found that chilli seed treated with thiram, aureofungin, captafol, vitavax and topsin each at 0.3 per cent concentration enhanced the seedling length and germination. (Gupta et al. 1992), found that chilli seeds treated with captan $2 \mathrm{~g}$ per $\mathrm{kg}$ of seed and kept in tin container after 12 months of storage retained higher germination $(86 \%)$ than the untreated seeds stored in cloth bag (55\%). (Sitara \& Hasan 2011), reported that chilli seed treated with 8 fungicides viz., Ridomyl Gold (68\% WP), Mancozeb (80\% w/w Dithiocarbamate), Antracol (70\%WP Propineb), Met al.axyl + Mancozeb (72\% w/w), Derosol (60\% WP Carbendazim), Aliette (80\% WP Fosetyle aluminium), Thiophonate methyl (70\% WP), and Copper oxychlorite $(50 \% \mathrm{WP})$ and four seed powders of herbicides viz., mustard (Brassica campestris), black cumin (Nigella sativa), asafetida (Ferula assafoetida) and neem (Azadirachta indica) were used. Ridomyl Gold @ 0.15\% \& 0.25\% found to be effective one which inhibited the fungal growth whereas Nigella sativa powder and asafetida@0.25\% were found to be more effective. However, reduced fungicidal activity toward Fusarium moniliforme was observed. So that their results cannot be compared with the present study results due to the difference in fungicide treatments.

\section{Conclusion}

Highest healthy seed germination was recorded in Mancozeb 80\% WP (1.562gm 100\% and 0.36gm 98\% healthy plants and $1.562 \mathrm{gm} 0 \%$ and $0.36 \mathrm{gm} 0.2 \%$ infected plants). Infected plants in control condition was $46.68 \%$. Similarly healthy and infected percentage of chili seeds treated with Carbendazim 50\% WP $1 \mathrm{gm}$ and $0.25 \mathrm{gm}$ gives similar result $92 \%$ healthy plants and $8 \%, 6.67 \%$ infected plants. In control conditions $40 \%$ were infected plants. Based on results obtained from the present study, it was concluded that among two fungicides; Mancozeb 80\% WP and Carbendazim 50\% WP. Mancozeb 80\% WP found to be the best for controlling the seed-borne fungi and also enhanced the seed germination rate.

\section{Acknowledgment:}

I would like to pay thanks to the government of Jilin Province for funding under the Jilin Government Fund on ACB Control (20150101073JC) and under the Ministry of Science and Technology of China (2017YFD0201804-5). I am very thankful to respected Prof. Chenrizhao of College of Plant Protection, Jilin Agricultural University, Changchun 130118, PR China, for his kind supervision and support.

\section{Conflict of interest:}

There is no conflict of interest.

\section{References:}

Adiver, SS et al. (1987). Seed mycoflora of chilli and their role in seed germination. Current Research 16, 70-72.

Ahmed, SS et al. (1982). Studies on Seed Borne Aspects of Anthracnose of Chilies Caused by Colletotrichum capsici (Sydow.). Butler and Bisby.M. Sc. (Agri.) Thesis, University of Agricultural Sciences, Bangalore.

Ahmed, SM \& Iqbal, A. (1989). Root and Collar-rot of chilies caused by Phytophthora capsici waterhouse. A new record for Pakistan Journal of Agricultural Research 27, 155-156.

Amusa, NA, Kehinde, IA \& Adegbite, AA. (2004). Pepper (Capsicum frutescens) fruit anthracnose in humid forest region of South-western Nigeria. Nutrition \& Food Science 34(3), 130-134.

Anonymous. (1976). International Rules for Seed Testing. International Seed Testing Association (ISTA). Seed Science and Technology 24 (supplement), 29-72.

Anonymous. (2006). Agriculture Statistics of Pakistan, 2005-2006. Ministry of Food and Agricultural and Livestock, Govt. of Pakistan, Islamabad.

Asaduzzaman, M, Alam, MJ \& Islam, MM. (2010). Effect of Trichoderma on Seed Germination and Seedling Parameters of Chilli. Journal of Science Foundation 8(1\&2), 141-150.

Asalmol, MN, Kale, VP \& Ingle, ST. (2001). Seed Borne Fungi of Chili, Incidence and Effect on Seed Germination. Seed Research. 29(1), 76-79.

Barnett, HL \& Hunter, BB. (1972). Illustrated Genera of Imperfect Fungi”, Burgess Publication Ltd, St. Paul, Minnesota, USA, pp.241.

Chauhan, RT, Patel, PR \& Thumar, VM. (2018). Occurrence of seed borne pathogens in Chilli (Capsicum 
frutescence L.) Cv. GVC 111 in vitro. P-ISSN: 2349-8528 E-ISSN: 2321-4902 International Journal of Chemical Studies 6(2), 1374-1376.

Dhawale, SP. (1975). Mycoflora of chilli seed its effects on germination and viability of seeds and chemical control. M. Sc. (Agri.) Thesis, Haryana Agriculture University Jharia.

Dhyani, AP et al. (1991). Seed health testing of red pepper and bell pepper with special reference to the pathogenicity and control of Myrothecium verrucaria. International Journal of Tropical Plant Diseases 9 , 207-220.

Chigoziri, E \& Ebenezer, EJ. (2013). Seed borne fungi of Chilli Pepper (Capsicum frutescens) from pepper producing areas of Benue State, Nigeria. AGRICULTURE AND BIOLOGY JOURNAL OF NORTH AMERICA. ISSN Print: 2151-7517, ISSN Online: 2151-7525, doi:10.5251/abjna.2013.4.4.370.374.

Ellis, MB. (1971). Demataceous hyphomycetes, Commonwealth Mycological Institute. Ferry Lane, Kew Surrey, UK pp.680.

Grover, RK \& Bansal, RD. (1970). Seed borne nature of Colletotrichum capsici in chilli seeds and its control by seed dressing fungicides. Indian Phytopathology 23, 664-668.

Gupta, A, Singh, D \& Maheshwari, VK. (1992). Effect of containers on the viability of fungicide treated chilli seeds. Seed Research 20(2), 160-161.

Hafeez, A. (1986). Plant Diseases. Khurseed Printers (Pvt) Ltd. Islamabad PARC, pp. 552.

Hemannavar, V. (2008). Studies on Seed Borne Aspects of Anthracnose of Chilli and Its Management. MS Thesis, Department of Plant Pathology, College of Agriculture, University of Agricultural Sciences, Dharwad-580005.

Hussain, A, Ahmed, MN \& Akhter AS. (1990). Protect chilies crop from Phytophthora, a new disease in Pakistan. Capsicum Newsletter 59, 8-9.

Islam, SS et al. (2007). Efficacy of Fungicidal Seed Treatment in Controlling Alternaria spp. In Radish Seed. International Journal of Sustainable Crop Production 2(5), 46-50.

Khaleeque, MI \& Khan, SM. (1991). Fungi associated with fruit rot and die back diseases of Chilies in Faisalabad. Pakistan Journal of Phytopathology 3, 50-52.

Koteshwar-Rao, O et al. (1962). Effect of seed treatment of chilli with organic fungicides in improving germination. Andhra Agriculture Journal 9, 55-59.

Kumar, S \& Mahmood, M. (1986). Evaluation of fungicides against colletrotichum capsicithe incident of die back and fruit rot of chilli. Pesticides 20(4), 28-29.

Mesta, RK. (1996). Studies on Fruit Rot of Chilli Caused by Colletotrichum capsici (Sydow.). Butler and Bisby. M. Sc. (Agri.) Thesis, University of Agricultural Sciences, Dharwad.

Mushtaq, M \& Hashmi, MH. (1997). Fungi associated with disease of capsicum in Sindh, Pakistan. Pakistan Journal of Botany 29(2), 217-222.

Narein, A \& Panigrahi, C. (1971). Efficiency of fungicidal compounds to control Colletotrichum capsici in vitro and in vivo. Indian Phytopathology 24(3), 593-596.

Pamplona-Roger GD. (2007). Healthy Foods. Editorial Safeliz, Spain Pp375.

Perane RR, \& Joi, MB. (1988). Studies on Seed Borne Infection of Fruit Rot and Dieback of Chilies. Journal of Maharashtra Agriculture University 13, 231-232.

Saleem, A et al. (1998). Effect of Physical parameters on the incidence of root and collar rot disease in Chilies. Pakistan Journal of Botany 30(1), 39-43.

Saleem, A et al. (1996). Mycoflora associated with root and collar rot disease of chilies in different districts of the Punjab (Pakistan). Pakistan Journal of Botany 9, 80-84.

Siddique, M, Dharamsingh, R \& Guar, A. (1977). Prevalence of chilli anthracnose fungus on seed and effective control. Seed Research 5(1), 67-72.

Sitara, U \& Hasan, N. (2011). Studies on the efficacy of chemical and non-chemical treatments to control mycoflora associated with chilli seed. Pakistan Journal of Botany 43(1), 95-110.

Srivastava, RN \& Gupta, JS. (1981). Seed borne fungi of pansy: Significance and control. Seed Research 9(2): 92-96.

Sultana, N, Khanzada, AK \& Aslam, M. (1992). A new caused of fruit rot of chilies in Pakistan. Pakistan Journal of Scientific and Industrial Research 35, 491-492.

Than, PP et al. (2008). Chili anthracnose disease caused by Collectotrichum species. Journal of Zhejiang University of Science 9(10), 764-778. 
Tables:

Table 1: Healthy and infected percentage of chili seeds treated with Mancozeb $80 \%$ WP

\begin{tabular}{|l|l|l|l|l|l|}
\hline \multirow{2}{*}{} & \multicolumn{5}{|c|}{ Mancozeb 80\% WP Conc./mg } \\
\cline { 2 - 6 } & 1.562 & 0.781 & 0.39 & 0.195 & Control \\
\hline Healthy & 100 & 80 & 97.32 & 80 & 53.36 \\
\hline Infected & 0 & 20 & 2.68 & 20 & 46.68 \\
\hline
\end{tabular}

Table 2 : Healthy and infected percentage of chili seeds treated with Carbendazim $50 \%$ WP

\begin{tabular}{|l|l|l|l|l|l|}
\hline & \multicolumn{5}{|c|}{ Carbendazim 50\% WP Conc./mg } \\
\cline { 2 - 6 } & 0.125 & 0.25 & 0.5 & 1 & Control \\
\hline Healthy & 78.68 & 93.36 & 81.36 & 92 & 60 \\
\hline Infected & 21.33 & 6.68 & 18.68 & 8 & 40 \\
\hline
\end{tabular}

Figures:

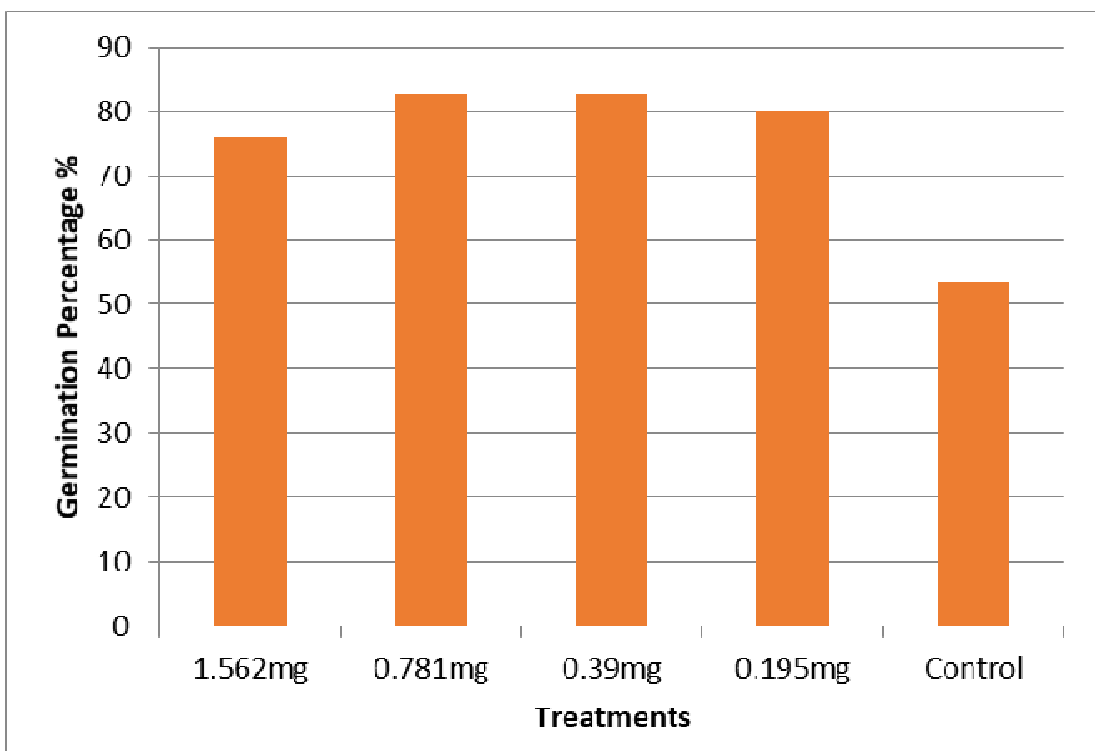

Fig 1: Germination \%age of chili seeds treated with Mancozeb 80\% wp

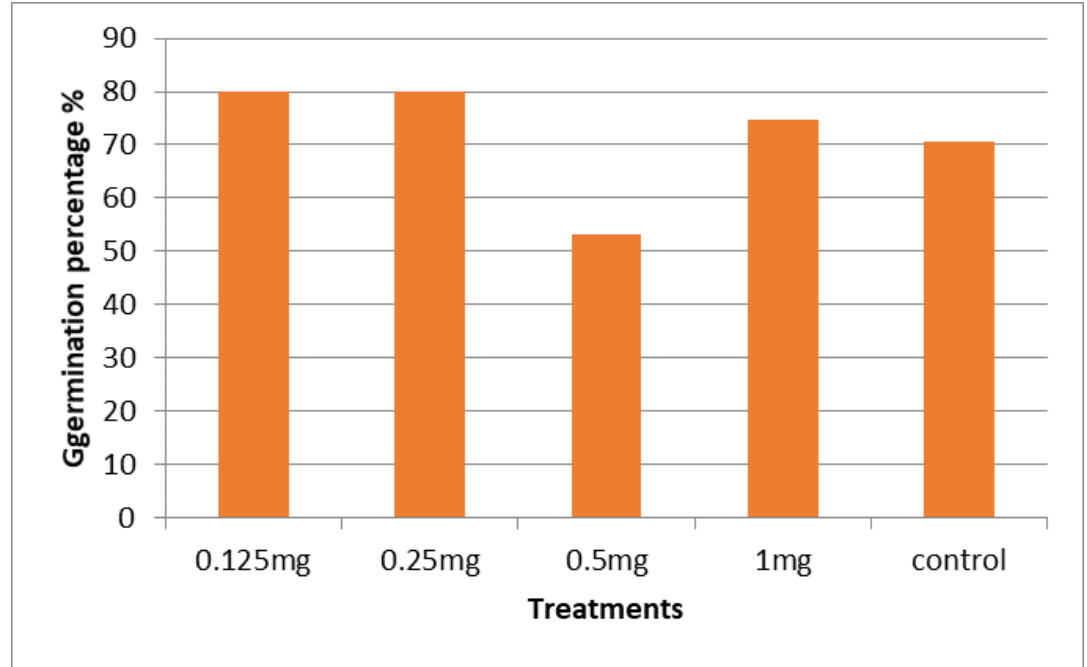

Fig 2: Germination \%age of chili seeds treated with Carbendazim 


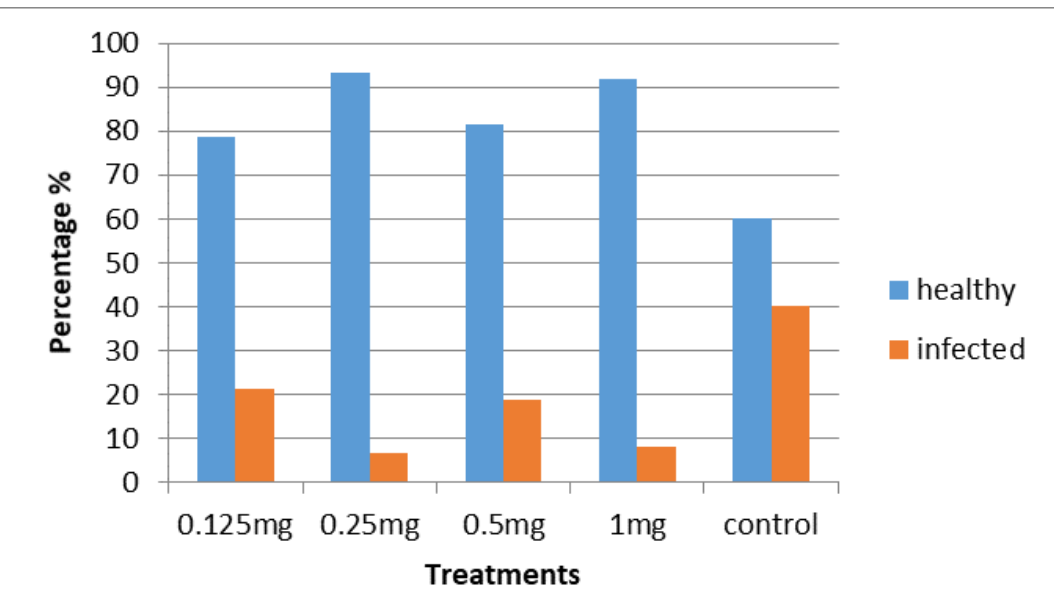

Fig 3: Healthy and infected percentage of chili seeds treated with Carbendazim $50 \%$ WP

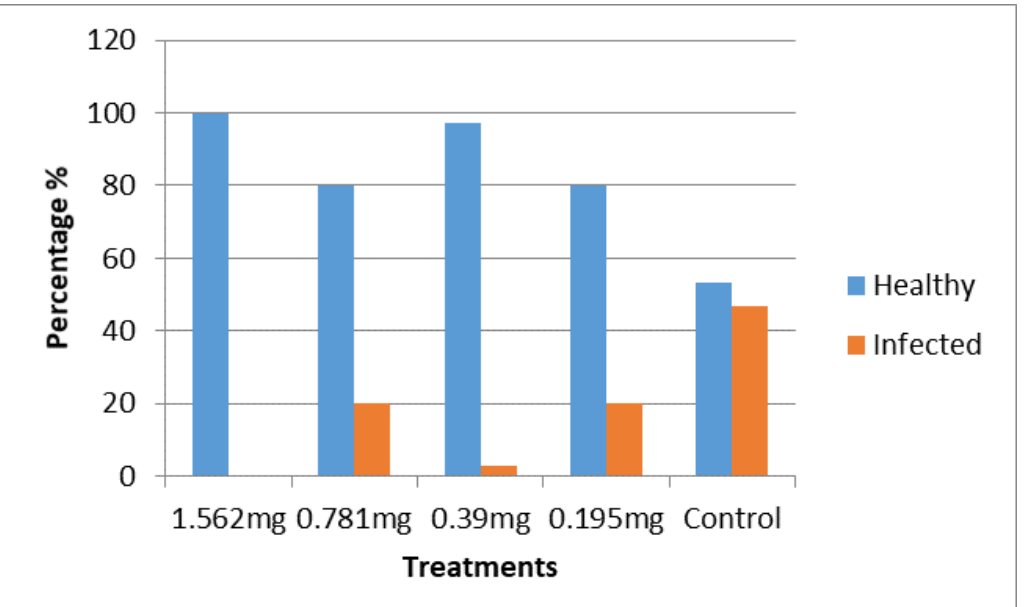

Fig 4: Healthy and infected percentage of chili seeds treated with Mancozeb $80 \% \mathrm{WP}$
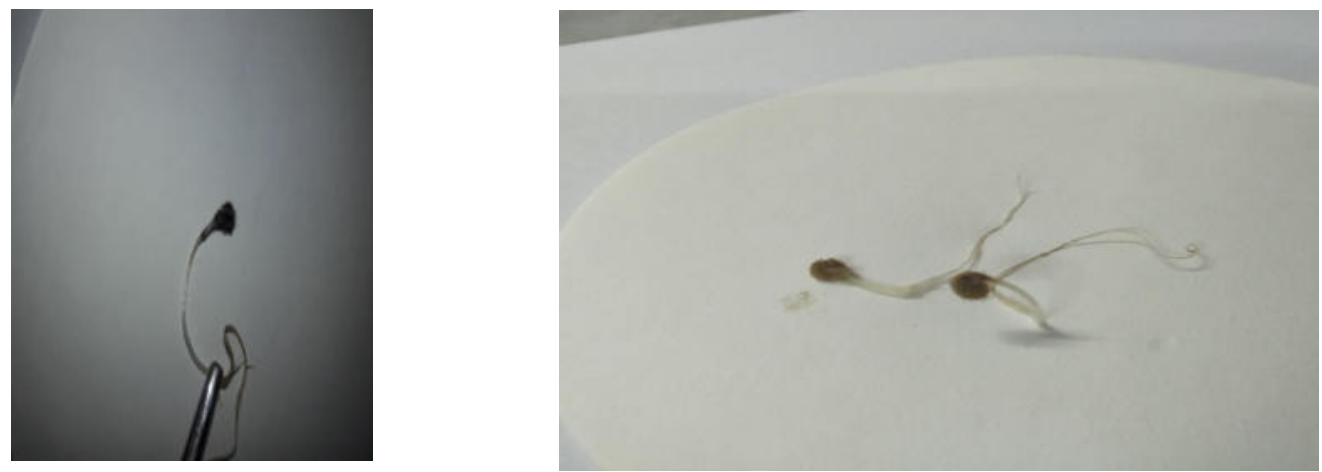

(A) Aspergillus niger

(B) Aspergillus flavous

Fig 5: Infection levels of two fungal species (A) Aspergilla's nigras and (B) Aspergilla's flavous 